\title{
Modelling the housing market in OECD Countries
}

P. Arestis ${ }^{\mathrm{a}, \mathrm{b}} *$ and A.R. González ${ }^{\mathrm{a}}$

aDepartment of Land Economy, University of Cambridge, Cambridge, UK; bDepartment of Applied Economics V, University of the Basque Country, Bilbao, Spain

\begin{abstract}
Recent episodes of housing bubbles, which occurred in several economies after the burst of the United States housing market, suggest studying the evolution of housing prices from a global perspective. We utilise a theoretical model for the purposes of this contribution, which identifies the main drivers of housing price appreciation, as for example, income, residential investment, financial elements, fiscal policy and demographics. In a second stage of our analysis, we test our theoretical hypothesis by means of a sample of 18 OECD countries from 1970 to 2011 . We employ the vector error correction econometric technique in terms of our empirical analysis, which permits us to model the long-run equilibrium relationship and the short-run dynamics, which also helps to account for endogeneity and reverse causality problems.
\end{abstract}

Keywords: empirical modelling, housing market, vector error correction modelling, OECD countries.

JEL Classification: C22, R31. 


\section{Introduction}

The occurrence of several episodes of housing bubbles in a number of developed economies in the second half of the 2000s, suggests the necessity of identifying the main drivers of this market.

In order to contribute to the existing debate, we begin by proposing a theoretical explanation of housing prices, which puts forward the role of the basic fundamentals of this market, for example, disposable income, real residential investment, mortgage rates and demographics. Our model also accounts for the behaviour of monetary authorities by including credit standards. Moreover, in our specification there is room for the public sector to perform its role by means of taxation. We then proceed to test the validity of our theoretical model by applying cointegration analysis (Johansen, 1995), on a sample of 18 OECD economies during the period 1970-2011. Our econometric results assure the existence of a long-run relationship among the variables and capture the adjustment in the short run by means of a Vector Error Correction Model (VECM) - also accounts for endogeneity and reverse causality problems.

In terms of economic policy our analysis upgrades the role of the prudential and fiscal policies in relation to monetary policy. Moreover, our results also point to disposable income as the corner stone of the model.

The remainder of this paper is organised as follows. Section 2 presents a review of those contributions, which are relevant to our theoretical model. In section 3 the econometric technique employed is discussed. Section 4 discusses the data and section 5 displays the estimations undertaken for this study. Section 6 discusses our results in comparison with other contributions. Finally, section 7 summarises and concludes.

\section{Literature review of variables of interest}

An external shock in demographics, income or changes in the behaviour of fiscal or monetary authorities modifies households' preference for properties. This change provokes a disequilibrium, which is absorbed by prices, since supply of dwelling is given in the short run. The existence of a new level of housing prices creates an incentive to property developers to alter the supply of housing over a longer period. As a result, there is a change in the flow of new residential assets, which 
modifies the supply of housing. At the same time, a strong effect in terms of unemployment and income emerges, which is related to construction activities. In this context, households determine the volume of housing assets that they desire to acquire and apply for bank credit to enable them to purchase of this asset. Changes in housing prices modify the share of households who are able to enter the market, which finally affects demand for housing and 'feeds' this cycle. The system collapses when the banking sector perceives a high level of households' indebtedness that induces a tightening of credit standards and increases in interest rates since borrowers' risks are higher. As a result, there is a decline in housing demand and adjustment emerges until a new position of equilibrium is reached.

In this context, the main determinant of housing prices is real disposable income, $Y_{D}$. More precisely, the demand for housing is driven by dwelling affordability, which is defined as the income-to-price ratio (OECD, 2005). ${ }^{1}$ Any increase in households' income that makes more affordable to purchase a property fuels demand for housing and induces an increase in housing prices appreciation since supply of housing is given in the short run. This positive effect, which emanates from income, has also been pointed by previous contributors, for example, Bover (1993), Poterba (1984) and Klyuev (2008) among others.

The supply side of the housing market is also important in the determination of housing prices, i.e. the role of real residential investment, $I_{R}$, has to be considered. ${ }^{2}$ The role that this element plays in the determination of housing prices varies depending on the time horizon under consideration. In the short run the housing market displays peculiar dynamics, i.e. quantities and prices move in the same direction (Igan and Loungani, 2012). More specifically, an increase in real estate investment exerts a positive effect on house price appreciation. This is due to the fact that increasing households' desires to purchase housing assets increases the demand for housing. This hike in demand drives housing prices up since the supply of housing is fixed over this time horizon. This positive relationship is maintained until the point is reached where property developers increase the production of dwellings and homeowners start to sell their assets in order to materialise those extraordinary capital gains that are produced by the high housing prices. As a result, there is an increase in the supply of housing, which curbs house price appreciation.

\footnotetext{
${ }^{1}$ The price-to-income ratio can be utilised as an indicator of housing prices overvaluation. Specifically, a strong deviation between this ratio and its long-run average could suggest the development of a bubble in this market (OECD, 2005).

${ }^{2}$ Real residential investment captures the flow of real estate assets, which are produced during a given time period (Nobili and Zollino, 2012).
} 
The relevance of the positive effect that emanates from the volume of banking credit, $C_{B}$, on housing prices cannot be ignored. ${ }^{3}$ The volume of bank credit is a reflection of the credit standards, which the Central Bank establishes by means of prudential policy. Commercial banks have to identify credit-worthy demand according to the conditions defined by the Central Bank and be willing to provide those mortgages, which derive from the solvent demand for credit at the rate of interest established by the monetary authorities. ${ }^{4}$ Credit standards and the cost of external finance are determined by considering the value of households' collateral, which is influenced by housing prices. ${ }^{5}$ In terms of our approach a relaxation in credit standards permits the entrance in the housing market of more potential buyers, who can obtain those financial resources that are needed to purchase real estate assets. As a result, an expansionary shift of demand for housing takes places which fuels housing prices. More specifically, the role of credit market as related to the housing market has to be discussed in the context of the 'financial accelerator' (Bernanke and Gertler, 1989; Bernanke et al. 1996; Bernanke et al. 1999).

The 'financial accelerator', or 'credit multiplier', is supported by three main arguments: (a) internal finance is always more affordable than external finance, independently of the value of the collateral that backs the loan, which is due to lenders' agency cost; (b) agents' risk premium is negatively related to their net wealth, i.e. internal funds (liquid assets) and collateral (illiquid assets); ${ }^{6}$ (c) a decline in agents' net wealth induces a hike in the risk premium that provokes a rise in the volume of external funds that borrowers require and finally slows down borrowers' spending and production (Kiyotaki and Moore, 1997; Bernanke et al. 1996). ${ }^{7}$ Specifically, Bernanke et al. (1996) focus on the empirical evidence in which small

\footnotetext{
${ }^{3}$ In our approach the volume of bank credit is approximated by the domestic credit to the private sector as a percentage of GDP.

${ }^{4}$ See Lavoie (1984).

5 There is also an important indirect effect on economic activity through the so called 'wealth' effect, which emanates from unexpected increases in housing prices. In particular, there is a vast economic literature that considers households' wealth as the main determinant of consumption. In this sense, a decline in housing prices induces a decrease to the value of households' wealth, which mainly corresponds to real estate assets. As a result, households reduce their demand for final goods, i.e. a decline in consumption takes place, and finally a negative effect on the level of economic activity emerges (see, also, Nneji et al., 2013).

${ }^{6}$ Bernanke et al. (1999) point to the existence of a positive risk premium as a natural phenomenon in a banking system characterized by the presence of 'agency' problems.

${ }^{7}$ Bernanke and Gertler (1989) develop a model applied to the channels utilised by firms' in order to finance their investment decisions. Bernanke and Gertler (op. cit.) conclude that the impact of the financial accelerator is more powerful in those cases where the economy is in recession. Kiyotaki and Moore (1997) display a dynamic model where procyclical and endogenous changes in the price of the assets determine net wealth, the volume of banking credit that firms can withdraw and their spending. The Kiyotaki and Moore's (op. cit.) model considers the existence of credit limits and the evolution of assets prices as the main explanatory elements to explain the amplification effect of changes in credit on the economy.
} 
variations, for example oil price fluctuations or changes in monetary policy, provokes an important effect on aggregate economic activity. Bernanke et al. (op. cit.) define the 'financial accelerator' as the amplification of real or monetary shocks in the economy due to variations in credit conditions. This notion suggests that variations in credit-market conditions enhance and extend the impact in which emanates from monetary or real shocks. ${ }^{8}$ In this context any kind of negative shocks, which curb the economic expansion, harden financial conditions and complicate the entrance of agents in the credit market, while agents' credit necessities increase. ${ }^{9}$ As a result, there is a slowdown of spending which accelerate the downturn of the economy. ${ }^{10}$ Bernanke et al. (1996) also coin the term 'flight to quality', which refers to a situation where agents have to deal with higher agency cost and as a result the volume of credit that they can receive is lower.

Furthermore, the negative impact of the cost of banking finance, i.e. mortgage rates, $R_{M}$; on housing prices has to be mentioned. The acquisition of a property is the main investment decision that households undertake by getting into debt. Economic literature suggests that an increase in the mortgage rate reduces the affordability of housing assets. ${ }^{11}$ This fact compels some potential buyers to abandon the market. As a result, this decline in demand for housing curbs housing prices. The mortgage rate accounts for one of the channels through which monetary authorities can affect the dynamics of the housing market. ${ }^{12}$

Moreover, policy makers have an important and effective 'tool' to influence the evolution of housing prices and avoid the development of bubbles in this market, i.e. fiscal policy. ${ }^{13}$ The most powerful channel that fiscal authorities could use in order to alter the dynamics of the market is taxation on property. ${ }^{14}$ The justification of this

\footnotetext{
${ }^{8}$ Eckstein and Sinai (1986) point to the hypothesis that agents tend to be overindebted and in a weak position to face cyclical peaks.

9 A decline in agents' net wealth provokes an increase in the cost of external resources, which means a fall in borrowers demand for credit. However, at the same time there is an increase in the funds that are require to repay the fixed obligations since the volume of internal funds is reduced.

${ }^{10}$ Bernanke et al. (1996) explain the 'financial accelerator' in a context of 'principal-agent' conflicts, i.e. the 'financial accelerator' could be identified with endogenous variations of the agency cost of lending. The 'principal-agent' framework describes a situation where lenders cannot obtain the information that they would know about borrowers without facing a cost.

${ }^{11}$ Iossifov et al. (2008) study the interest rate elasticity of residential housing prices. Iossifov et al. (op. cit.) point out that the acquisition of real estate assets is undertaken by means of external finance since the price of this asset is a multiple of home buyers' disposable income.

${ }^{12}$ See de Leeuw and Gramlich (1969) for an explanation of those channels that monetary authorities can utilise to influence the housing market. See, also, Shiller (2007) for a discussion of the role played by low interest rates in the development of assets bubbles since 1990s.

${ }^{13}$ Fiscal policy could impact the housing market by means of several instruments; for instance, reducing mortgage interest payments, subsidies, taxation over property, capital gains levies and public expenditure.

${ }^{14}$ Muellbauer (2003) highlights the role of taxation with respect to regulations in the use of land.
} 
statement is the fact that a high level of taxation could modify households' preferences for dwelling by making the decision of renting the properties more attractive than purchasing them. ${ }^{15}$ Our approach assumes a negative effect of fiscal policy on housing prices since an increase in property taxation rises the user's cost of home ownership. This increase curbs the demand for housing and housing prices as a result since there are some households who are not interested in purchasing real estate assets under the new conditions. According to their preferences to rent the services of the asset becomes more profitable than buying the property. ${ }^{16}$ Our proposal follows Hilbers et al. (2008) and includes the tax revenues-to-housing prices ratio, $T$, to account for the role of taxation in the housing market.

Finally, we account for the influence of demographic elements, which are an important driver of the demand for housing. On the one hand, there is a positive correlation between the growth of population, $D_{P O}$, and housing prices. A positive shock of population, i.e. rising population due to the natural trend of growth of population or inflows of immigrants, fuels demand for housing since the share of potential buyers that need to consume the services provided by real estate assets is higher. ${ }^{17}$ This increase in demand is absorbed by higher prices in the short-run since supply is given and property developers cannot satisfy immediately this rising demand. This positive relationship is especially strong in those areas, which are highly populated, due to the fact that the constraints regarding the availability of land to produce new assets, i.e. the supply for housing becomes more inelastic, reinforces this mechanism. ${ }^{18}$

On the other hand, our testable hypothesis includes the negative effect that emanates from the presence of unemployment, $D_{U N}$. Rising unemployment curbs demand for housing since those households who loose their employment suffer a reduction of their income, which makes less affordable the purchase of the assets. ${ }^{19}$ Previous contributions, Cameron and Muellbauer (2001), also consider housing

\footnotetext{
${ }^{15}$ See Hilbers et al. (2008) for details of taxation related to the housing market in the vast majority of the countries that we analyse in the empirical part of this contribution.

${ }^{16}$ Capozza et al. (1998) emphasize the negative effects of taxation on housing prices and provide empirical evidence of this fact by using a sample of 63 metropolitan areas in the United States during the period 1970-1990. Haffner and Oxley (2011) discuss the influence of taxation on house price volatility in Denmark, Germany, the Netherlands, the United Kingdom and the United States. However, Fuest et al. (2004) suggest that taxation on capital gains could raise the volatility of housing prices.

${ }^{17}$ Holly and Jones (1997) study the impact of demographics in the United Kingdom during the period 1939-1994. Bover (1993) focuses on the Spanish housing market.

${ }^{18}$ See Miles (2012) who analyses the United Kingdom housing market.

${ }^{19}$ See, also, Ni et al. (2011) who focuses on the role of unemployment in the United States housing market and Zhu (2010) for further empirical evidence in the case of the United Kingdom.
} 
ownership as a determinant of unemployment, since housing ownership reduces the willingness of unemployed workers to move to others areas. Moreover, unemployment also exerts other indirect effects in the housing market. For example, unemployment is an indicator of the level of economic activity, which is utilised by agents in order to elaborate their expectations. Under the presence of this phenomenon, some households decide to postpone their investment decisions until the moment in which the economic situation changes. At the same time, commercial banks will be more reluctant to issue new mortgages in this kind of context since their risk perception is growing. All these facts induce a decline in demand for housing, which curbs housing prices appreciation. We also may note that rising unemployment exert an additional effect on housing prices, since some home owners have to sell their assets due to the fact that they cannot repay their mortgages and try to get rid of their obligations before defaulting. Additionally, an increase in foreclosures also slows down housing prices appreciation.

The previous discussion can be encapsulated as in equation (1) which summarises the testable hypothesis that we utilise for the purposes of the empirical part of this contribution:

$P_{H}=P_{H}\left(Y_{D}, I_{R}, C_{B}, R_{M}, T, D_{U N}, D_{P O}\right)$

where $P_{H}$ stands for real housing prices, $Y_{D}$ for real disposable income, $I_{R}$ for real residential investment, $C_{B}$ for the volume of banking credit, $R_{M}$ for the mortgage rate, $T$ for the ratio of taxation to property/house price, $D_{U N}$ for the rate of unemployment, and $D_{P O}$ for the evolution of population. The sign below a variable indicates the partial derivative of $P_{H}$ with respect to that variable.

\section{Econometric specification}

This section begins with the stationarity of the data under consideration, which is checked by means of the augmented Dickey-Fuller (Dickey and Fuller; 1979, 1981) tests, the Phillips-Perron (Phillips and Perron, 1988) test and the GLS-based DickeyFuller (Nelson and Plosser, 1982) test. The null hypothesis of these three tests is the existence of a unit root. We also apply the Kwiatkowski-Phillips-Schmidt-Shin (Kwiatkowski et al., 1992) test, whose null hypothesis is the absence of unit roots, i.e. the stationarity of the time series. Unit root/stationarity tests are utilised to check 
whether the data are integrated of first-order. The justification of this way of proceeding is due to the fact that in some cases, for example, if the variable displays structural breaks, the unit root/stationarity tests could identify unit roots instead of stationarity with structural changes. In our particular case, all these tests suggest the presence of unit root, which is the pre-condition in the application of the cointegration analysis. $^{20}$

Subsequently, we proceed to estimate the proposed relationship by using the Vector Error Correction Model (VECM; see, for example, Johansen, 1995). In the VECM case there is no need to make assumptions about the direction of the causality and the existence of temporal causality relationships amongst the variables involved, since all variables are jointly determined at the same time. The fact that this technique is based on VAR modelling allows the relaxation of the assumptions regarding the exogeneity or endogeneity of the explanatory variables. ${ }^{21}$ This approach permits to overcome problems of endogeneity of the regressors and reverse causality, which cannot be dealt with easily by means of other techniques, such as for example, instrumental variables. ${ }^{22}$ In this framework, firstly, we conduct a preliminary test to calculate the length of the lag that our VECM computes. ${ }^{23}$ Secondly, we apply the Johansen test for cointegration (Johansen, 1988, 1991), which studies the existence of relationships among the variables in question and indicates the number of cointegrating relationships that can be estimated. ${ }^{24}$ As a result, we proceed to estimate the VECM that produces the dynamics in the short run and provides the cointegrating parameters in its normalized form, which constitutes a long-run equilibrium relationship. ${ }^{25}$ For the particular purpose of this contribution we estimate the VECM, which is specified in equation (2):

$\Delta P_{H}=\beta_{0}+\sum_{i=1}^{n} \varphi_{11} \Delta P_{H t-i}+\sum_{i=1}^{n} \varphi_{12} \Delta X_{t-i}+\alpha_{0} E_{t-1}+\varepsilon_{t}$

where $P_{H}$ accounts for real house prices; $X$ is a vector which computes the following variables: real disposable income, $Y_{D}$, real residential investment, $I_{R}$, the volume of banking credit, $C_{B}$; mortgage rate, $R_{M}$; the ratio of taxation to property/house price, $T$,

\footnotetext{
${ }^{20}$ The results of these unit root/stationarity tests are shown in the Appendix.

${ }^{21}$ A VAR (n) is characterized by utilising as explanatory elements of each equation $n$ lags of each variable which is included in the model.

${ }^{22}$ Gonzalo (1994) states the superiority of this technique even in those cases where the dynamics of the variables are unknown or there is no normality in the residuals.

${ }^{23}$ This test is conducted by means of the STATA command varsoc.

${ }^{24}$ The STATA command vecrank is used to run this test.

${ }^{25}$ The estimation of the VECM is performed by the command vec.
} 
the rate of unemployment, $D_{U N}$, and the population, $D_{P O} . E$ is the error-correction term, $\varepsilon$ is a random error term, and $\beta_{0}, \alpha_{0}, \varphi_{11}$ and $\varphi_{12}$ are the estimated parameters. All the variables are computed in logarithms except the mortgage rate.

The validity of the short-run estimations is checked by the standard diagnostic/statistics that are reported in previous contributions that apply the same econometric technique. More precisely, we present the R-squared (R-sq), the Chisquared test (chi2), the Akaike Information Criterion (AIC), the Breusch-Godfrey Serial Correlation LM (Breusch, 1979; Godfrey, 1978) statistic, the Schwartz Bayesian Information Criterion (SBIC) and the Hannan-Quinn Information Criterion (HQIC). ${ }^{26}$

\section{Utilised data}

The validity of our testable hypothesis is checked by utilising a sample of 18 OECD economies during the period 1970-2011. Particularly, the economies under consideration are the following: Australia, Belgium, Canada, Denmark, Finland, France, Germany, Italy, Ireland, Japan, Netherlands, New Zealand, Norway, Spain, Sweden, Switzerland, the United Kingdom and the United States. This sample permits us to conduct a comparative study among the most important developed countries, which are different enough in terms of their banking sectors, taxation systems, incomes and demographic factors, although their housing cycles are synchronized through time. The lack of homogeneous information before 1970 regarding housing prices compels us to start our analysis in $1970 .^{27}$

The AMECO databank of the European Commission's Directorate General for Economic and Financial Affairs is the principal source of the annual data provided. More precisely, the variables employed are the following: (a) Gross Fixed Capital Formation by type of Goods at Current Prices (Dwelling), ${ }^{28}$ (b) Gross National Disposable Income per Head of Population; (c) Real Long-term Interest Rate; ${ }^{29}$ (d)

\footnotetext{
${ }^{26}$ See Pulido and Pérez (2001) for further details on these tests.

${ }^{27}$ Real Housing Price Index are available at the website of the Bank of International Settlements (BIS): http://www.bis.org/

${ }^{28}$ The OECD databank Gross fixed capital formation, housing is utilised in the case of Norway and Switzerland.

${ }^{29}$ The presence of missing information in the AMECO long-term interest rate time series is replaced by using the $O E C D$ databank for Switzerland, New Zealand, Australia, Norway and Canada.
} 
Unemployment Rate; (e) Total Population; ${ }^{30}$ and (f) Gross Domestic Product Price Deflactor. $^{31}$

Furthermore, other data providers have been consulted: the Organisation for Economic Co-operation and Development (OECD), which offers annual data regarding Taxation over immovable property (\% of GDP); and the World Bank, which publishes Domestic Credit to Private Sector (\% of GDP). ${ }^{32}$

STATA 11 and EViews 5.0 are the econometric packages utilised in order to estimate the econometric relationships and derive the relevant statistics/diagnostics.

\section{Empirical results}

\subsection{Preliminary analysis and long-run relationships}

The length of the lag that the VECM includes is selected by applying the Akaike Information Criterion (AIC), the Hannan-Quinn Information Criterion (HQIC) and the Schwartz Bayesian Information Criterion (SBIC). We consider a maximum of four lags as reasonable to account for the dynamics of this market, especially so since annual data is utilized. Such a lag length should be sufficient for the majority of the duration of each phase of the cycle. ${ }^{33}$ Another important consideration is that such lag length also allows the model to have enough degrees of freedom. ${ }^{34}$ The selected length in all cases varies between 2 and 4 lags. ${ }^{35}$

Table 1 reports the results of the Johansen's trace test for cointegration (Johansen, 1988, 1991) and confirms the existence of one cointegrating equation in each case. The first column presents the maximum rank, i.e. the number of cointegrating equations that exist among the variables under consideration. ${ }^{36}$ The second column shows the values of the log-likelihood function, which are utilised to study the possibility of restricting a VAR of a given order to another VAR of lower

\footnotetext{
${ }^{30}$ The OECD databank Population Statistics provides the missing information in the event of Germany from 1970 to 1991.

${ }^{31}$ These time series can be downloaded at:

http://ec.europa.eu/economy_finance/db_indicators/ameco/index_en.htm

${ }^{32}$ These databases can be consulted at:

http://data.worldbank.org/; http://stats.oecd.org/index.aspx

${ }^{33}$ OECD (2005) points out that the contraction stage of the housing market spans for 5 years while the expansionary one could last for up to 6 years.

${ }^{34}$ Our lag length is along the lines of other contributions, which also use annual data; see, for example, Holly and Jones (1997).

${ }^{35}$ The results of this test are cited in the Appendix (Table 9).

${ }^{36}$ The rank of a matrix is the number of its characteristic roots, which are different from 0 (Brooks, 2008).
} 
order. The third column reports the eigenvalues, which are calculated in order to conduct the test. The fourth and the fifth columns display the trace statistics and the critical values at the 5\% significance level. In all the cases we strongly reject the null hypothesis of no cointegration. However, we cannot reject the null hypothesis of at most there is one cointegrating equation. As a result the output presented in Table 1 confirms the existence of one cointegrating equation. ${ }^{37}$

Table 1. Johansen test for cointegration.

\begin{tabular}{|c|c|c|c|c|c|}
\hline \multicolumn{6}{|c|}{ Johansen tests for cointegration } \\
\hline & maximum rank & LL & eigenvalue & trace statistic & $5 \%$ critical value \\
\hline Australia & 1 & 26.5159 & 0.5175 & 24.4202 & 29.68 \\
\hline Belgium & 1 & 31.3226 & 0.5597 & 21.9956 & 29.68 \\
\hline Canada & 1 & 40.3057 & 0.5871 & 16.9803 & 29.68 \\
\hline Denmark & 1 & 61.5947 & 0.3750 & 12.1370 & 15.41 \\
\hline Finland & 1 & 129.8274 & 0.6377 & 9.0885 & 15.41 \\
\hline France & 1 & 292.8084 & 0.4188 & 13.9409 & 15.41 \\
\hline Germany & 1 & 352.4996 & 0.4935 & 21.6469 & 29.68 \\
\hline Ireland & 1 & 196.3465 & 0.3903 & 12.6203 & 15.41 \\
\hline Italy & 1 & 280.2785 & 0.5333 & 26.0087 & 29.68 \\
\hline Japan & 1 & 323.2638 & 0.5301 & 26.2700 & 29.68 \\
\hline Netherlands & 1 & 209.5143 & 0.5117 & 28.6008 & 29.68 \\
\hline New Zealand & 1 & 287.3301 & 0.6233 & 25.8829 & 29.68 \\
\hline Norway & 1 & 326.00000 & 0.5417 & 45.0277 & 47.21 \\
\hline Spain & 1 & 254.9385 & 0.5728 & 45.5246 & 47.21 \\
\hline Sweden & 1 & 217.0000 & 0.7994 & 41.8044 & 47.21 \\
\hline Switzerland & 1 & 362.5041 & 0.6576 & 27.4091 & 29.68 \\
\hline UK & 1 & 431.9571 & 0.6144 & 45.5785 & 47.21 \\
\hline US & 1 & 374.0071 & 0.5394 & 29.4883 & 29.68 \\
\hline
\end{tabular}

The normalized parameters which are estimated for the cointegrating equations are shown in Table $2 .^{38}$ Specifically, the coefficients of the long-run relationships are normalized with respect to real housing prices. As a result, the parameter on real housing prices is unity. ${ }^{39}$

\footnotetext{
37 The Johansen's trace test for cointegration considers as its null hypothesis that the number of cointegrating vectors is less than or equal to $r$. Its alternative hypothesis is that there are more than $r$ cointegrating vectors. See, also, Brooks (2008) and StataCorp. (2009), for further details.

${ }^{38}$ Normalizing a given vector means obtaining a proportional vector, relative to the initial one, whose magnitude is equal to one (see, also, Brooks, 2008).

${ }^{39}$ The normalization which is applied can be described as follows. If there are $r$ cointegrating relationships, at least $r^{2}$ restrictions are needed to identify the free parameters in $\eta$. Johansen (1995) suggests the following identification scheme:

$\eta^{\prime}=\left(I_{r}, \tilde{\eta}^{\prime}\right)$
}

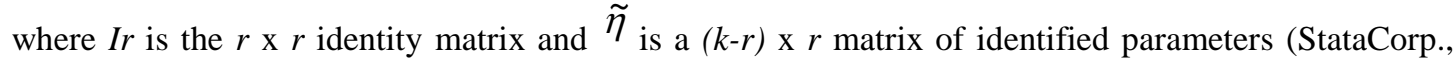
2009). 
Table 2. Long-run relationships.

\begin{tabular}{|c|c|c|c|c|c|c|c|c|c|}
\hline & Constant & $\mathrm{L}_{-} \mathrm{P}_{\mathrm{H}}$ & $\mathrm{L}_{-} \mathrm{Y}_{\mathrm{D}}$ & $\mathrm{L}_{-} \mathrm{I}_{\mathrm{R}}$ & $\mathrm{L}_{-} \mathrm{C}_{\mathrm{B}}$ & $\mathrm{R}_{\mathrm{M}}$ & $\mathrm{L}_{-} \mathrm{T}$ & $\mathrm{L} \_\mathrm{D}_{\mathrm{UN}}$ & L_DPO \\
\hline Australia & -22.2042 & 1 & & & & & $-3.4938 * * *$ & $0.3362 * * *$ & $-4.3416^{* * *}$ \\
\hline Belgium & -7.4023 & 1 & $-0.7364 * * *$ & & & & $-0.1125^{* *}$ & & $-4.7702 * * *$ \\
\hline Canada & 3.5053 & 1 & $-7.9711 * * *$ & & & $-12.9195^{* * * *}$ & & & $15.9202 * * * *$ \\
\hline Denmark & -5.2854 & 1 & & & $-0.3535^{* * *}$ & & & $-0.2491 * * *$ & \\
\hline Finland & -8.1336 & 1 & & & & & $-0.2332 * * *$ & & $-2.5805^{*} * *$ \\
\hline France & -20.5767 & 1 & & & & & & $-0.5292 * * *$ & $-16.0024 * * *$ \\
\hline Germany & -9.3527 & 1 & $0.6921 * * *$ & $0.5585^{* * * *}$ & $-1.1060 * * *$ & & & & \\
\hline Ireland & -1.5389 & 1 & $-0.8667 * * *$ & & & & & $0.1396^{* * * *}$ & \\
\hline Italy & 1.7715 & 1 & $-1.4185^{* * * *}$ & & & & & $0.9251 * * *$ & \\
\hline Japan & -23.3930 & 1 & $1.8618^{* * *}$ & & $-1.4440 * * *$ & & $-1.1231 * * *$ & & \\
\hline Netherlands & 2.3718 & 1 & & & & & $3.9858 * * * *$ & $-2.3811 * * *$ & $-7.2301 * * *$ \\
\hline New Zealand & 5.7959 & 1 & $-4.2650 * * *$ & & & & $-1.6773 * * *$ & & $4.0455^{* * *}$ \\
\hline Norway & 1.8573 & 1 & $-0.5975 * * *$ & $-0.8599 * * *$ & & & $-0.3459 * * *$ & & $2.2988 * * *$ \\
\hline Spain & -10.0231 & 1 & $-4.9821 * * *$ & $3.40395 * * *$ & & & $-0.0660 * * *$ & & $-4.6614 * * *$ \\
\hline Sweden & 12.8830 & 1 & $-2.6284 * * *$ & & & $-14.2841^{* * * *}$ & $0.5732 * * *$ & & \\
\hline Switzerland & 102.0127 & 1 & -18.2373 **** & & $-6.1358 * * *$ & & & & $52.6011^{* * * *}$ \\
\hline UK & -25.4913 & 1 & $0.6446^{* *}$ & & & $-8.8406 * * *$ & $-1.5948^{* * * *}$ & & $-17.5986^{* * * *}$ \\
\hline US & 7.2600 & 1 & & & $-0.6380^{* * * *}$ & $9.3697^{* * *} *$ & $3.3553 * * *$ & & \\
\hline
\end{tabular}

The estimated relationships shown in Table 2 point to real disposable income, which is one of the main determinants of dwelling affordability, as the most important variable in the explanation of housing prices in the long-run. Specifically, the cointegrating equations reveal a positive relationship between income and real housing prices in the long run in the following economies: Belgium, Canada, Germany, Ireland, Italy, Japan, New Zealand, Norway, Spain, Sweden, Switzerland and the United Kingdom. ${ }^{40}$

Real residential investment also contributes to explaining housing prices development in the long run in the particular cases of Germany, Norway and Spain. Demographic elements, are also highlighted since they play an important role in the evolution of demand for housing, and are a key element in the determination of real housing price appreciation. The relevance of demographics in the explanation of housing prices has been suggested by previous contribution such as Miles (2012), which is focused on the United Kingdom. In particular, the growth of population exerts a significant impact in the case of Australia, Belgium, Canada, Finland, France, the Netherlands, New Zealand, Norway, Spain, Switzerland and the United Kingdom. Regarding the second demographic variable that our analysis considers, i.e. unemployment, these cointegrating relationships confirm that this variable contributes

\footnotetext{
${ }^{40}$ Holly and Jones (1997) also suggest the existence of a cointegrating relationship between housing prices and disposable income in the case in the United Kingdom.
} 
to the determination of the long-run equilibrium in the cases of Australia, Denmark, Finland, Ireland, Italy, and the Netherlands. ${ }^{41}$

An important conclusion of our long-run analysis is the fact that fiscal authorities by means of taxation could develop a more important role than monetary authorities by manipulating interest rates. ${ }^{42}$ In particular, there is a significant impact, which emanates from mortgages rates just in Canada, Sweden, the United Kingdom and the United States. However, taxation over immovable property contributes to the determination of the long-run equilibrium relationship in the case of Australia, Belgium, Finland, Japan, the Netherlands, New Zealand, Norway, Spain, Sweden, the United Kingdom and the United States.

Regarding monetary authorities' actions in this market, our results reveal that they can exert a stronger influence by means of prudential policy, i.e. by tightening the credit standards. This element, which is proxied by the volume of banking credit, is significant in Denmark, Germany, Japan, Switzerland and the United States.

In general terms, our study confirms the results pointed by Igan and Loungani (2012) where it is suggested that housing prices in the long run are mainly determined by local fundamentals, namely, growth of population and income.

\subsection{Analysis of the short-run dynamics}

The models that are estimated for the purpose of this contribution in order to analyse the dynamics in the short run are shown in Table 3.

Table 3. Short-run equations.

\begin{tabular}{|c|c|c|c|c|c|c|c|c|c|c|}
\hline \multicolumn{11}{|c|}{ Short-run Relationship } \\
\hline & Constant & $\Delta \mathrm{L}_{-} \mathrm{Y}_{\mathrm{D}}$ & $\Delta \mathrm{L}_{-} \mathrm{I}_{\mathrm{R}}$ & $\Delta \mathrm{L}_{-} \mathrm{C}_{\mathrm{B}}$ & $\Delta \mathrm{R}_{\mathrm{M}}$ & $\Delta \mathrm{L}_{-} \mathrm{T}$ & $\Delta \mathrm{L}_{-} \mathrm{D}_{\mathrm{UN}}$ & $\Delta \mathrm{L} \_\mathrm{D}_{\mathrm{PO}}$ & $\Delta \mathrm{L}_{-} \mathrm{P}_{\mathrm{H}}$ & EL_P $P_{H}$ \\
\hline Australia & -0.0105 & & & & & & & $2.2714 * *(1)$ & $0.5357 *(1)$ & $-0.1511^{* *}$ \\
\hline \multirow[t]{2}{*}{ Belgium } & $0.0384 * * *$ & & & & & $-0.0725^{* *}(2)$ & & & $0.8676^{* * * *}(1)$ & $-0.4070^{* * *}$ \\
\hline & & & & & & $-0.0647 *(3)$ & & & $0.4486^{* *}(3)$ & \\
\hline Canada & 0.0062 & & & & & & & & $0.4435^{* * *}(1)$ & $-0.0529 * * *$ \\
\hline Denmark & 0.0157 & & & & & & $-0.1128 * * *(1)$ & & $0.7938 * * *(1)$ & $-0.1563^{* * *}$ \\
\hline Finland & $0.1506^{* * * *}$ & & & & & $-0.1816^{* *}(2)$ & & & $0.9903 * * *(1)$ & $-0.4921^{* *}$ \\
\hline \multirow[t]{2}{*}{ France } & $0.0151^{* *}$ & & & & & & $-0.1913 * *(2)$ & & $0.9458 * * *(1)$ & $-0.0777 * * *$ \\
\hline & & & & & & & & & $-0.3833^{* * *}(2)$ & \\
\hline Germany & -0.0055 & & & $0.3140 *(2)$ & & & & & $0.5650 * * *(1)$ & $-0.1604 * * *$ \\
\hline Ireland & 0.0141 & & & & & & & & $0.6396 * * *(1)$ & $-0.2640 * * *$ \\
\hline \multirow[t]{2}{*}{ Italy } & -0.0002 & $1.1754 * *(2)$ & & & & & & & $0.4526 * * *(2)$ & $-0.5555^{* * *}$ \\
\hline & & $1.6457 * * *(3)$ & & & & & & & $0.2347 *(3)$ & \\
\hline
\end{tabular}

\footnotetext{
${ }^{41}$ The role of unemployment in the evolution of housing prices in the long run have been pointed out by previous contributions, such as, for example, Barot and Yang (2002). Barot and Yang (op. cit.) find a relevant effect of unemployment in the case of the United Kingdom, although in our particular case this coefficient is not significant.

${ }^{42}$ Our findings are in the same vein as those of Igan and Loungani (2012) who consider that interest rates do not play a very important role in the determination of global housing prices.
} 


\begin{tabular}{|c|c|c|c|c|c|c|c|c|}
\hline Japan & -0.0104 & $0.9515^{* * * * *}(1)$ & & $0.5065^{* * *}(1)$ & & & $0.3205^{* * *}(1)$ & $-0.0836^{* *}$ \\
\hline Netherlands & 0.0074 & & & & & & $0.6338^{* * * *}(1)$ & $-0.0479^{* * *}$ \\
\hline New Zealand & -0.0015 & & & & $-0.3157^{*}(2)$ & $3.0488^{* * *}(2)$ & $0.4710^{* * * *}(1)$ & $-0.3806^{* * * *}$ \\
\hline \multirow[t]{3}{*}{ Norway } & 0.0333 & & & & $-0.4220^{* * * *}(1)$ & $1.2589^{*}(2)$ & $1.3163^{* * *}(1)$ & $-0.4458^{* * *}$ \\
\hline & & & & & $-0.3689^{* * * *}(2)$ & & $0.7205^{* *}(2)$ & \\
\hline & & & & & $-0.1985^{* * * *}(3)$ & & $1.3915^{* * * *(3)}$ & \\
\hline Spain & 0.0156 & & $0.6472 * *(1)$ & & & & $0.4748^{* * *}(1)$ & $-0.0884 * *$ \\
\hline Sweden & 0.0014 & & & & $-2.5317^{* * * *(1)}$ & & $0.6668 * * *(1)$ & $-0.2134 * * *$ \\
\hline \multirow[t]{3}{*}{ Switzerland } & -0.0032 & & & & & $1.7194 * * *(1)$ & $0.5371^{* * *}(1)$ & $-0.0527 * * *$ \\
\hline & & & & & & $0.5329^{* *}(2)$ & $-0.3335^{* * *}(2)$ & \\
\hline & & & & & & $1.0958^{* * *}(3)$ & $-0.2360^{*}(3)$ & \\
\hline UK & -0.0028 & $1.6433^{* *}(1)$ & & & $-1.3988 * *(1)$ & & $0.3547 *(1)$ & $-0.1566^{*}$ \\
\hline \multirow[t]{3}{*}{ US } & $0.0147 * *$ & & & & $-0.8211^{*}(2)$ & & $1.0233^{* * *}(1)$ & $-0.0873^{* *}$ \\
\hline & & & & & & & $-0.5121 *(2)$ & \\
\hline & & & & & & & $-0.6068 * *(3)$ & \\
\hline
\end{tabular}

Note: *,** and $* * *$ indicate statistical significance and rejection of the null at the $10 \%, 5 \%$ and $1 \%$ significance levels, respectively. Numbers in parentheses, in the case of the variables, show the lag(s) of the relevant variable.

The VECMs which are shown in Table 3 show how in the short run real housing prices in the previous periods are a significant explanatory element of the evolution of housing prices in the present. This finding supports the ideas advanced by Shiller (2007), which highlight the powerful role of expectations in the formation of prices in this market and also emphasize the fact that during booms households decide to buy this kind of asset due to speculative reasons. These elements are especially relevant in the explanation of the dynamics of Belgium, France, Italy, Norway, Switzerland and the United States, where the short-run models insert several lags of real housing prices.

These estimations also reveal a positive effect of real disposable income on real housing prices in the case of Italy (1.1754 and 1.6457), Japan (0.9515) and UK (1.6433). However, the impact of this variable is much more general in the long run.

Real residential investment is only significant in the case of Spain (0.6472). The effect of this variable in this particular market is maintained regardless of the time horizon considered. As discussed in Section 2, in the short run real residential investment contributes to fuel housing price appreciation.

These results also confirm the argument that the relaxation of credit standards permits the entrance of new home buyers in the market and favours an increase in the demand for housing, which is absorbed by prices. This impact is evident in the cases of Germany (0.3140) and Japan (0.5065), where the cointegrating equations also highlight the significance of this variable in these economies at the equilibrium position.

Moreover, fluctuations of mortgage rates curb housing price appreciation in the case of Sweden (-2.5317), the United States (-0.8211) and the United Kingdom (- 
1.3988). These findings are consistent in the long run, although in a longer time horizon our econometric results also pointed to a negative effect in the Canadian case.

Regarding the intervention of fiscal authorities in this market, our econometric results provide empirical evidence of how they can slowdown hikes in housing prices by means of taxation over property in the case of Belgium (-0.0725 and -0.0647), Finland (-0.1816), New Zealand (-0.3157), and Norway (-0.4220, -0.3689 and 0.1985). This variable is also significant in the determination of housing prices in the equilibrium relationship.

Finally, we may note that the role of demographics factors in the short-run study follows the same pattern that is found in the long-run analysis. The positive effect, which emanates from the growth of population, is more important than the negative one that appears in the event of unemployment. In particular, unemployment is just relevant in Denmark (-0.1128) and France (-0.1913), where this effect is also significant in the long run in both markets. However, the evolution of population is a driver of housing prices in Australia (2.2714), New Zealand (3.0488), Norway (1.2589) and Switzerland (1.7194, 0.5329 and 1.0958). The relevance of this demographic factor in those economies is also pointed above in the case of the longrun analysis.

The last column in Table 3 reports the value of the error-correction term, which indicates the proportion of disequilibria between the short-run dynamics and the cointegrating relationship that is dropped out in each period. The estimations show how between a $5 \%$ and $10 \%$ of the disequilibria is eliminated in Canada, France, Japan, the Netherlands, Spain, Switzerland and the United States. More dynamic is the housing market in Australia, Denmark, Germany, and the United Kingdom where the speed of adjustment is around 15\%-16\%. The differences in disequilibria between the short-run and the long-run are reduced slightly faster in the case of Sweden (20\%) and Ireland (26\%). This percentage rises twice in the case of Belgium, New Zealand and Norway (between 40-45\%). The most dynamic markets of the sample under consideration are the Finish and the Italian ones, where the error-correction terms are $50 \%$ and $56 \%$ respectively.

Table 4. Short-run equations: Diagnostics/statistics.

\begin{tabular}{lcccccc}
\hline Diagnistic/Statistics & \multicolumn{1}{c}{} & & & \\
\hline & $\mathrm{R}-\mathrm{sq}$ & $\mathrm{LM}(1)$ & $\mathrm{LM}(2)$ & AIC & HQIC & SBIC \\
\hline Australia & 0.5400 & $11.0725(0.8049)$ & $8.6140(0.9284)$ & -12.5347 & -12.1207 & -11.3711 \\
Belgium & 0.8115 & $14.4587(0.5645)$ & $13.2798(0.6522)$ & -14.4834 & -13.5778 & -11.9146 \\
Canada & 0.3644 & $10.5187(0.8381)$ & $16.8928(0.3925)$ & -19.2850 & -18.8717 & -18.1333 \\
Denmark & 0.4518 & $6.7345(0.6647)$ & $1.1247(0.9990)$ & -2.2869 & -2.0267 & -15.6176
\end{tabular}




\begin{tabular}{|c|c|c|c|c|c|c|}
\hline Finland & 0.7589 & $12.2407(0.2000)$ & $12.8484(0.1695)$ & -8.3435 & -7.8702 & -6.6371 \\
\hline France & 0.7537 & $5.4317(0.7951)$ & $8.0472(0.5294)$ & -13.8644 & -13.4665 & -12.7554 \\
\hline Germany & 0.5112 & $12.9895(0.6735)$ & $17.3518(0.3632)$ & -17.2251 & -16.5658 & -15.3720 \\
\hline Ireland & 0.7701 & $11.4062(0.2488)$ & $16.2195(0.0624)$ & -9.1972 & -8.9370 & -8.4721 \\
\hline Italy & 0.8152 & $7.2696(0.6090)$ & $12.0498(0.2105)$ & -10.9906 & -10.4539 & -9.4823 \\
\hline Japan & 0.6395 & $17.6975(0.3419)$ & $20.5436(0.1967)$ & -15.1930 & -14.7798 & -14.0413 \\
\hline Netherlands & 0.6696 & $10.1914(0.8564)$ & $12.0381(0.7413)$ & -9.6060 & -9.1920 & -8.4424 \\
\hline New Zealand & 0.7781 & $15.0927(0.5178)$ & $12.5596(0.7046)$ & -16.5667 & -15.6634 & -13.9180 \\
\hline Norway & 0.7625 & $18.4167(0.8242)$ & $29.0636(0.2612)$ & -16.6910 & -15.3249 & -12.8161 \\
\hline Spain & 0.7007 & $24.8467(0.4709)$ & $24.5402(0.4883)$ & -11.1660 & -10.1847 & -8.4079 \\
\hline Sweden & 0.7892 & $18.1561(0.3148)$ & $18.1749(0.3137)$ & -13.7921 & -13.4159 & -12.4856 \\
\hline Switzerland & 0.9092 & $6.3034(0.9844)$ & $31.1308(0.0129)$ & -17.6312 & -16.7256 & -15.0624 \\
\hline UK & 0.4853 & $29.5902(0.2400)$ & $28.9812(0.2647)$ & -20.1516 & -19.5547 & -18.4880 \\
\hline US & 0.8142 & $15.6865(0.4750)$ & $12.5552(0.7049)$ & -17.8862 & -16.9806 & -15.3174 \\
\hline
\end{tabular}

The first column of Table 4 shows the value of the R-squared. In the case of Canada and Denmark the model displays the less powerful adjustment (36 and 45\%). This statistic explains half of the variation in housing prices in the United Kingdom, Germany, and Australia (49\%, 51\% and 54\% respectively). In the case of Japan this percentage is higher (64\%) and slightly superior in the event of the Netherlands (67\%) and Spain (70\%). The statistic also explains around the $80 \%$ of the short-run fluctuations of real housing appreciation in France (0.75), Finland (0.76), Ireland (0.77), New Zealand (0.78), Norway (0.76), Sweden (0.79), Belgium (0.81), Italy (0.82) and the United States (0.81). The higher adjustment is reached in the case of the Swiss market (91\%). The second and the third columns of Table 4 display the results of the the Breusch-Godfrey Serial Correlation LM (Breusch, 1979; Godfrey, 1978) statistic, which tests for the lack of autocorrelation of first- and second-order. In all the cases the null hypothesis of absence of autocorrelation is accepted. Moreover, the last 3 columns of this table display the value of the Akaike Information Criterion (AIC), the Schwartz Bayesian Information Criterion (SBIC) and the Hannan-Quinn Information Criterion (HQIC). All these statistics permit to select the specification that fits in well with the structure of the data. These criteria are utilised in those cases where there are several alternatives for the same model. Particularly, econometric literature (Pulido and Pérez, 2001) recommends choosing that model, which presents the lower value of this statistic. All these diagnostics/statistics validate our theoretical and econometric analyses.

\section{Comparison with other cross-country studies}

We also check the validity of our findings by comparing them with the results of previous contributions. 
Regarding the role of income in the evolution of dwelling prices, Miles and Pillonca (2008) find a positive relationship between real house appreciation and real income growth in the case of Norway, Ireland, the Netherlands and Italy. These findings are supported by our cointegrating equations in all cases except for the Netherlands. Moreover, Miles and Pillonca (2008) emphasise the positive effect, which emanates from an increase in population in Spain and the United States. André (2010) also highlights the same effect in the case of Ireland, Spain, New Zealand, Canada and the United States. Our long-run results suggest the same impact in these countries except for the United States and Ireland where the evolution of population has no influence in the long-run equilibrium relationship.

Furthermore, the role of the supply side of the housing market has also been discussed by André (2010), who analyses the impact of residential investment on real house prices and points to a strong relationship between these two variables in the case of Ireland, Spain, Canada and the Nordic economies. Our results also confirm the existence of a relationship between these elements in the case of Spain and Norway.

To continue with the review of our results, we compare our short-run estimations with those of Igan and Loungani (2012). ${ }^{43}$ Specifically, Igan and Loungani (op. cit.) find that housing prices are explained by the evolution of population and long-term interest rates in Belgium, while in France the determinants are income, population, and long-term interest rate. However, our estimations point to taxation and unemployment as the explanatory elements in Belgium and France respectively. We may note that the lack of impact of credit in France and Belgium, which is found by Igan and Loungani (2012) and also pointed out by Hilbers et al., 2008) support our estimations.

Igan and Loungani's (2012) results advance some findings that are along the lines suggested by our estimations as reported in the previous relevant section. For example, in the case of Australia, New Zealand and Norway both contributions consider a positive relationship between housing prices and population. The common driver, which is identified by both studies for the German and the Japanese markets, is credit. There is also a positive common effect of income in the United Kingdom and Japan. Moreover, the effect of interest rates that is suggested by our empirical

\footnotetext{
${ }^{43}$ Igan and Loungani (2012) model housing prices as a function of dwelling affordability, income per capita, working-age population, stock prices, credit, short-term interest rates and long-term interest rates. Their sample spans from 1970 to 2010. The inclusion of housing affordability, lagged one period, is considered as an error-correction term. This is in view of the use of their contribution to compare it with our short-run models.
} 
findings in the cases of Sweden, the United Kingdom and the United States is supported by the above mentioned study.

However, our results do not exhibit common elements with Igan and Loungani (2012) in the case of Canada, Denmark, Finland, Ireland, Italy, the Netherlands, Spain and Switzerland. For instance, our empirical results show how in the short run the error-correction term and lagged housing prices are the unique drivers of housing price dynamics in Canada, Ireland and the Netherlands. However, Igan and Loungani (2012) find that housing prices are explained by income, credit, short-term interest rates in the Netherlands; by income and credit in Ireland; and by long-term interest rates and income in Canada. In the Spanish case, the Igan and Loungani's (2012) model concludes that housing prices are determined by means of the evolution of working-age population and credit, while our estimations capture the impact of real residential investment. Moreover, in the case of Switzerland Igan and Loungani (op. cit.) highlight income and long-term interest rate as the important explanatory elements; in the case of our results a significant positive impact of the rate of growth of population is found.

\section{Summary and conclusions}

A model for the determination of housing prices is proposed in this contribution. The impact of traditional variables such as income, interest rates of loans for housing and demographics is found important. Our theoretical proposition also includes the role of two participants in this particular market, i.e. fiscal and monetary authorities. The validity of our testable hypothesis is checked by means of cointegration analysis.

The results of our research show different channels through which public authorities can influence the housing market. First, the most important instrument that they can utilise is fiscal policy. Specifically, they can alter income, which is the key determinant of the demand for housing, the engine of the model, by means of taxation over income, e.g. personal income tax and imputed rental levies, such as subsidies, e.g. mortgage interest deductibility, and public expenditure. This tool becomes really important after the recent bust of the housing market, since any kind of public attempt to contribute to the recovery of the sector should emanate from an improvement of households' income. Second, taxation over property cannot be ignored as a relevant factor to change households' preference for real residential assets. As pointed out by 
Muellbauer (2003), this sort of policies is much more effective than regulation of the use of land. In particular, a high level of property and wealth taxation could discourage households to purchase real estate assets, since renting properties becomes a more attractive option. At the same time, the acquisition of a second or a third residence could be curbed by a relevant levy. Another powerful instrument, which could also be used is capital gains taxation. Moreover, fiscal authorities should encourage the rental market as another measure to curb demand for housing among those households who are more inclined to default if the conditions of the economy change unfavorably, i.e. low-income individuals who are more likely to become unemployed.

On the other hand, our results point to the ineffectiveness of monetary policy, in the form of interest rate manipulation. In this sense, interest rates should be settled as low and stable as possible, since the banking sector has to provide the liquidity, which is required to permit the functioning of the sphere of production without creating distortions. At first sight, this policy recommendation could be controversial. However, monetary authorities may develop more important tasks in terms of prudential policy in order to guarantee a credit-worthy demand for credit and as a result the solvency of the banking sector.

Finally, monetary authorities should also consider the evolution of housing prices in order to define their objectives and the instruments that they can utilise to achieve them. This recommendation is easily justified by the recent 'great recession' outcomes, which clearly reveal that financial and macroeconomic instability is related to sharp fluctuations in asset prices.

\section{References}

AMECO. 2011. AMECO Databank List of Variables. Available at: http://ec.europa.eu/economy_finance/db_indicators/ameco/index_en.htm

André, C. 2010. “A Bird's Eye View of OECD Housing Markets”, OECD Economics Department Working Papers no. 746, Paris: OECD Publishing.

Barot, B., and Z. Yang. 2002. "House Prices and Housing Investment in Sweden and the UK: Econometric Analysis for the Period 1970-1998", Review of Urban \& Regional Development Studies, 14(2): 189-216.

Bernanke, B., and M. Gertler. 1989. "Agency Cost, Net Worth, and Business Fluctuations", American Economic Review, 79 (1): 14-31.

Bernanke, B., M. Gertler, and S. Gilchrist. 1996. "The Financial Accelerator and the Flight to Quality", Review of Economics and Statistics, 78 (1): 1-15. 
Bernanke, B., M. Gertler, and S. Gilchrist. 1999. "The Financial Accelerator in a Quantitative Business Cycle Framework", in J.B. Taylor and M. Woodford (eds.), Handbook of Macroeconomics, Amsterdam: North-Holland.

Bover, O. 1993. "Un Modelo Empírico de la Evolución de los Precios de la Vivienda en España (1976-1991)”, Investigaciones Económicas, 17 (1): 65-86.

Breusch, T. S. 1979. "Testing for Autocorrelation in Dynamic Linear Models", Australian Economic Papers, 17 (31): 334-355.

Cameron, G., and J. Muellbauer. 2001. "Earnings, Unemployment, and Housing in Britain”, Journal of Applied Econometrics, 16 (3): 203-220.

Capozza, D. R., R. K. Green, and P. H. Hendershott. 1998. "Taxes and House Prices", Working Paper, Ann Arbor: University of Michigan, available at: http://www.umich.edu/ reecon/restate/faculty/Capozza/tax1097b.pdf

de Leeuw, F., and E. M. Gramlich. 1969. "The Channels of Monetary Policy: A Further Report on the Federal Reserve-M.I.T. Model”, The Journal of Finance, 24 (2): 265-290.

Dickey, D. A., and W. A. Fuller. 1979. "Distribution of the Estimator for Autoregressive Time Series with a Unit Root", Journal of the American Statistical Association, 74 (366): 427-431.

Dickey, D. A., and W. A. Fuller. 1981. "Likelihood Ratio Statistics for Autoregresssive Time Series with a Unit Root”, Econometrica, 49 (4): 1057-1072.

Eckstein, O., and A. Sinai. 1986. "The Mechanism of the Business Cycle in the Post War Era", in R.J. Gordon (ed.) The American Business Cycle: Continuity and Change, Chicago: University of Chicago Press.

Feroli, M. E., E. S. Harris, A. Sufi, and K. D. West. 2012. "Housing, Monetary Policy, and the Recovery", Chicago Booth Paper no. 12-16, Chicago: University of Chicago.

Fuest, C., B. Huber, and S. O. Nielsen. 2004. "Capital Gains Taxation and House Price Fluctuations", Department of Economics Working Paper no. 16, Copenhagen: Copenhagen Business School.

Gonzalo, J. 1994. "Five Alternative Methods of Estimating Long-Run Equilirbrium Relationships", Journal of Econometrics, 60 (1-2): 203-233.

Godfrey, L. G. 1978. "Testing Against General Autoregressive and Moving Average Error Models when the Regressors Include Lagged Dependent Variables", Econometrica, 46 (6): 1293-1302.

Haffner, M., and M. Oxley. 2011. "House price volatility and taxation", available at: http://www.enhr2011.com/sites/default/files/Paper-Haffner\%20and\%20OxleyWS01new.pdf 
Hilbers, P., A. W. Hoffmaister, A. Banerji, and H. Shi. 2008. "House Prices Developments in Europe: A Comparison", IMF Working Paper no. 211, Washington, D.C.: International Monetary Fund.

Holly, S., and N. Jones. 1997. "House Prices since 1940s: Cointegration, Demography and Asymmetries", Economic Modelling, 14 (4), 549-565.

Igan, D., and P. Loungani. 2012. "Global Housing Cycles", IMF Working Paper 12/217, Washington, DC: International Monetary Fund.

Iossifov, P., M. Čihák, and A. Shanghavi. 2008. "Interest Rate Elasticity of Residential Housing Prices", IMF Working Paper no. 247, Washington, D.C.: International Monetary Fund.

Johansen, S. 1988. "Statistical Analysis of Cointegrating Vectors", Journal of Economic Dynamics and Control, 12 (2-3): 231-254.

Johansen, S. 1991. "Estimation and Hypothesis Testing of Cointegration Vectors in Gaussian Vector Autoregressive Models", Econometrica, 59 (6): 1551-1580.

Johansen, S. 1995. Likelihood-based Inference in Cointegrated Vector Autoregressive Models, Oxford: Oxford University Press.

Kiyotaki, N., and J. Moore. 1997. "Credit Cycles", Journal of Political Economy, 105 (2): 211-248.

Klyuev, V. 2008. "What Goes Up Must Come Down? House Price Dynamics in the United States", IMF Working Paper no. 211, Washington, D.C.: International Monetary Fund.

Kwiatkowski, D., P. C. B. Phillips, P. Schmidt, and Y. Shin. 1992. "Testing the Null Hypothesis of Stationarity against the Alternative of a Unit Root: How Sure Are We that Economic Time Series Have a Unit Root?", Journal of Econometrics, 54 (1-3): 159-178.

Lavoie, M. 1984. "The Endogenous Flow of Credit and the Post Keynesian Theory of Money", Journal of Economics Issues, 18 (3): 771-797.

Miles, D. 2012. "Demographics, House Prices and Mortgage Design", Bank of England External MPC Discussion Paper no. 35, London: Bank of England.

Miles, D., and V. Pillonca. 2008. "Financial Innovation and European Housing and Mortgage Markets", Oxford Review of Economic Policy, 24 (1): 145-175.

Muellbauer, J. 2003. "Housing, Credit and the Euro: the Policy Response", Economic Outlook, 27 (4): 5-13.

Nneji, O., C. Brooks, and C. Ward. 2013. "House Price Dynamics and Their Reaction to Macroeconomic Changes", Economic Modelling, Forthcoming.

Nobili, A., and F. Zollino. 2012. "A Structural Model for the Housing and Credit Market in Italy", Banca d'Italia Working Papers No. 887, Rome: Banca d'Italia. 
Ni, J. S., S. S. Huang, and Y. Wen. 2011. "Interest Rates, Unemployment Rate and House Market in US", IPEDR, 5 (1): 413-417.

OECD. 2005. "Recent House Prices Developments: The Role of Fundamentals", OECD Economic Outlook, 78: 123-154.

Phillips, P. C. B., and P. Perron. 1988. "Testing for a Unit Root in Time Series Regression", Biometrika, 75 (2): 335-346.

Poterba, J. M. 1984. "Tax Subsidies to Owner-Occupied Housing: An Asset-Market Approach", The Quarterly Journal of Economics, 99 (4): 729-752.

Pulido, A., and J. Pérez. 2001. "Modelos Econométricos”, Madrid: Pirámide.

StataCorp. 2009. Stata: Release 11. Statistical Software, College Station, TX: StataCorp LP.

Shiller, R. J. 2007. "Low Interest Rates and High Asset Prices: An Interpretation in Terms of Changing Popular Models", Cowles Foundation Discussion Paper No. 1632, Cowles Foundation for Research in Economics: Yale University.

Zhu, Q. 2010. "Regional Unemployment and House Price Determination", MPRA Paper no. 41785, Munich: Munich Personal RePEc Archive.

\section{Appendix. Unit root/cointegration tests.}

Table 5. ADF unit root tests.

\begin{tabular}{|c|c|c|c|c|c|c|c|c|}
\hline & $\mathrm{L}_{-} \mathrm{P}_{\mathrm{H}}$ & $L_{-} Y_{D}$ & $\mathrm{~L}_{-} \mathrm{I}_{\mathrm{R}}$ & $\mathrm{L}_{-} \mathrm{C}_{\mathrm{B}}$ & $\mathrm{R}_{\mathrm{M}}$ & $\mathrm{L} \_\mathrm{T}_{\mathrm{N}}$ & $\mathrm{L}_{-} \mathrm{D}_{\mathrm{UN}}$ & $\mathrm{L}_{-} \mathrm{D}_{\mathrm{PO}}$ \\
\hline Australia & $-5.2982 * * * *(4)$ & 2.8507 (2) & $-3.0046(4)$ & $-1.8183(0)$ & $-1.3664(0)$ & $-2.5085 * *(1)$ & $-3.2112^{* *}(0)$ & $-1.9483(1)$ \\
\hline Belgium & $-1.9236(1)$ & $-2.1387(1)$ & $-3.1985^{*}(2)$ & $-1.9048(0)$ & $-1.2442(0)$ & $-2.6511(0)$ & $-5.0267 * * * *(3)$ & $4.0261(6)$ \\
\hline Canada & $-1.9527(1)$ & $-2.9846(1)$ & $-2.2427(0)$ & $-2.5910(0)$ & $-1.2622(1)$ & $-2.0765(1)$ & $-2.5685^{* * *}(1)$ & $-2.0788(1)$ \\
\hline Denmark & $-2.1652(1)$ & $-3.5972 * *(1)$ & $-2.3749(1)$ & $-1.3862(0)$ & $-2.2578(0)$ & $-3.4438 *(1)$ & $-3.0947 * *(1)$ & $-2.1944(3)$ \\
\hline Finland & $-3.5550^{* * *}(1)$ & $1.5589(1)$ & $-0.8840(2)$ & $-3.5621^{* *}(3)$ & $-2.3028(0)$ & $-2.3944 * *(0)$ & $-3.2104 *(1)$ & $3.3692(2)$ \\
\hline France & $-2.1129(1)$ & $-2.7555(1)$ & $-2.2725(1)$ & $-0.4765(9)$ & $-4.3638 * * *(5)$ & $-1.8727 *(1)$ & $-3.2812^{* *}(0)$ & $3.7014(2)$ \\
\hline Germany & $-1.7289(1)$ & $-1.8246(1)$ & $-2.7355(1)$ & $-1.9252(0)$ & $-3.7681^{* * * *}(0)$ & $-2.1154(0)$ & $-2.7397^{*}(4)$ & $-2.2269(5)$ \\
\hline Ireland & $-2.8944(1)$ & $-2.1575(1)$ & $-2.2796(2)$ & $0.4095(0)$ & $-3.2084 * *(0)$ & $-2.5119(1)$ & $-2.2447(1)$ & $-3.0614(4)$ \\
\hline Italy & $-4.0186 * *(2)$ & $-3.1770 * *(1)$ & $-2.8449(1)$ & $-0.7788(1)$ & $-1.3782(0)$ & $0.5694(2)$ & $-2.3195(1)$ & $-2.3691(5)$ \\
\hline Japan & $-0.4896(1)$ & $-2.0642(1)$ & $-2.4718(1)$ & $0.0255(1)$ & $-2.9577 * *(0)$ & $-2.192392(0)$ & $-2.6748(1)$ & 0.1779 (3) \\
\hline Netherlands & $-2.8046(1)$ & $-2.1906(1)$ & $-2.4260(1)$ & $-0.2040(0)$ & $-0.7889(1)$ & $-2.0560^{* *}(1)$ & $-0.6375(2)$ & 0.6078 (3) \\
\hline New Zealand & $-2.3279(1)$ & $-1.7200(0)$ & $0.6546(0)$ & $-1.6181(0)$ & $-1.3500(1)$ & $-0.9109(0)$ & $-2.5938(3)$ & $9.8908(0)$ \\
\hline Norway & $-1.8988(1)$ & $4.2215(0)$ & $-2.4629(1)$ & $-2.9146(1)$ & $-3.9414^{* * * *}(0)$ & $-1.3153(0)$ & $-2.1364(2)$ & $2.5942(7)$ \\
\hline Spain & $-5.2982(4)$ & $-3.1179(1)$ & $-2.4507(1)$ & $-1.1083(2)$ & $-1.9446 *(0)$ & $-1.8180 *(0)$ & $-1.3114(1)$ & $-3.6149 * *(3)$ \\
\hline Sweden & $-1.9236(1)$ & $-2.1387(1)$ & $-3.1985^{*}(2)$ & $-2.6286(1)$ & $-1.2442(0)$ & $-1.7784 *(1)$ & $-1.0481(2)$ & $-2.8573(3)$ \\
\hline Switzerland & $-3.1067^{* *}(1)$ & $-3.6571 * *(1)$ & $-4.4112^{* * * *}(1)$ & $-0.9041(0)$ & $-2.6670^{*}(0)$ & $-0.6591(0)$ & $-3.0330(1)$ & $2.3807(4)$ \\
\hline UK & $-3.2409 *(1)$ & $-1.8444(1)$ & $-3.7694 * *$ (4) & $-1.0527(0)$ & $-3.9414 * * *(5)$ & $-3.5008 *(1)$ & $-2.2180(1)$ & $0.1731(1)$ \\
\hline US & $-3.6876^{* * * *}(4)$ & $-4.0024 * * * *(1)$ & $-2.9723(1)$ & $-2.1399(0)$ & $-0.7972(0)$ & $-3.0964(1)$ & $-3.3553^{* * *}(1)$ & $-3.4019 *(1)$ \\
\hline
\end{tabular}


Table 6. PP unit root tests.

\begin{tabular}{|c|c|c|c|c|c|c|c|c|}
\hline & $\mathrm{L}_{-} \mathrm{P}_{\mathrm{H}}$ & $\mathrm{L}_{-} \mathrm{Y}_{\mathrm{D}}$ & $\mathrm{L}_{-} \mathrm{I}_{\mathrm{R}}$ & $\mathrm{L}_{-} \mathrm{C}_{\mathrm{B}}$ & $R_{M}$ & $\mathrm{~L} \_\mathrm{T}_{\mathrm{C}}$ & $\mathrm{L}_{\_} \mathrm{D}_{\mathrm{UN}}$ & $\mathrm{L} \_\mathrm{D}_{\mathrm{PO}}$ \\
\hline Australia & 1.2548 & 3.6532 & $-3.6700^{* * *}$ & -1.9854 & -1.4142 & -2.1255 & -2.5275 & $-3.9359 * *$ \\
\hline Belgium & 2.3425 & -1.6859 & -2.3145 & -2.0152 & -1.2059 & -2.6728 & -2.1406 & 4.5198 \\
\hline Canada & 2.1357 & -2.5512 & -2.5907 & -2.5640 & -1.5024 & -0.7504 & -2.2257 & $-3.3161^{*}$ \\
\hline Denmark & 1.3458 & -2.5051 & -2.0444 & -1.4538 & -2.1041 & -2.6968 & -2.9726 & 5.1887 \\
\hline Finland & -1.5856 & -2.4659 & -2.3806 & -1.5962 & -2.3147 & -1.6973 & -2.1353 & 13.2134 \\
\hline France & 1.7714 & -2.6358 & 2.0110 & $-5.3414 * * *$ & -0.9212 & $-1.9943^{* * *}$ & -1.6198 & -1.9510 \\
\hline Germany & -1.5441 & -2.5057 & 1.5860 & -1.7097 & $-3.7681 * * *$ & -2.3388 & $-3.7432^{*}$ & 1.1653 \\
\hline Ireland & 0.9552 & 1.9107 & -0.7761 & 0.4095 & $-3.0253 * *$ & $-1.6191 *$ & -0.8230 & 4.5151 \\
\hline Italy & 1.0434 & 0.5517 & -2.2624 & 0.2402 & -1.3683 & 0.9328 & -1.9986 & 3.0464 \\
\hline Japan & -0.1551 & -2.3242 & -2.4382 & -2.0162 & $-2.9577 * *$ & -2.5143 & $-2.3805^{* * *}$ & 3.1115 \\
\hline Netherlands & 1.3464 & 3.3170 & 1.5892 & -0.2040 & -1.0443 & $-1.7624^{*}$ & -1.4375 & 9.9951 \\
\hline New Zealand & 2.0443 & -1.7601 & 0.4314 & -1.7802 & $-1.7130 *$ & -1.3810 & $-2.6198^{*}$ & 7.7153 \\
\hline Norway & -1.3014 & 4.3478 & 0.9945 & -2.1658 & $-3.7533^{* *}$ & -1.4626 & -1.8575 & 2.8295 \\
\hline Spain & 1.2548 & -1.0645 & 1.0127 & 0.6697 & $-2.0825 * *$ & -1.7295 & $-2.0918^{* *}$ & 4.5768 \\
\hline Sweden & 2.3425 & -1.6859 & -2.3145 & $-4.0937^{* * *}$ & -1.2059 & $-1.7467 *$ & -1.2369 & 1.4030 \\
\hline Switzerland & 0.6506 & -2.9847 & -2.4126 & -0.9407 & $-2.7447 *$ & -0.7894 & -1.3230 & 2.3064 \\
\hline UK & 2.0946 & 3.5358 & 1.2009 & -1.0553 & $-3.1832 * *$ & -2.5472 & -2.2351 & 2.3898 \\
\hline US & 0.8208 & -2.6700 & -1.8573 & -2.1399 & -0.8694 & -1.4585 & -2.1132 & -1.4551 \\
\hline
\end{tabular}

Note: $* * *$ and $* * *$ indicate statistical significance and rejection of the null at the $10 \%, 5 \%$ and $1 \%$ significance levels, respectively.

Table 7. KPSS unit root tests.

\begin{tabular}{|c|c|c|c|c|c|c|c|c|}
\hline & $\mathrm{L}_{-} \mathrm{P}_{\mathrm{H}}$ & $L_{-} Y_{D}$ & $\mathrm{~L}_{-} \mathrm{I}_{\mathrm{R}}$ & $\mathrm{L}_{-} \mathrm{C}_{\mathrm{B}}$ & $\mathrm{R}_{\mathrm{M}}$ & $\mathrm{L} \_\mathrm{T}_{\mathrm{N}}$ & $\mathrm{L}_{-} \mathrm{D}_{\mathrm{UN}}$ & $\mathrm{L}_{-} \mathrm{D}_{\mathrm{PO}}$ \\
\hline Australia & 0.0828 & $0.1638^{* * *}$ & 0.0812 & $0.7598 * * *$ & $0.1590^{* * *}$ & 0.1049 & $0.2586^{* * * *}$ & $0.8172^{* * * *}$ \\
\hline Belgium & $0.1720^{* * *}$ & $0.8011^{* * * *}$ & $0.6802^{* *}$ & $0.7430^{* * *}$ & 0.1574 & $0.6401^{* * *}$ & $0.3824 *$ & $0.7742^{* * * *}$ \\
\hline Canada & 0.1183 & 0.1036 & 0.0867 & $0.6990^{* * *}$ & 0.1673 & $0.4394 * *$ & $0.1895^{* * *}$ & $0.1846^{* * *}$ \\
\hline Denmark & $0.1753^{* *}$ & $0.7850^{* * * *}$ & $0.1796^{* *}$ & $0.1649 * *$ & $0.1680^{* * *}$ & $0.1479 * *$ & $0.1800^{* * *}$ & $0.1671 * *$ \\
\hline Finland & $0.5690^{* *}$ & $0.7717^{* * * *}$ & $0.7011 * *$ & $0.4796^{* *}$ & $0.1837 * *$ & $0.1205^{*}$ & $0.1199^{*}$ & $0.1531 * *$ \\
\hline France & $0.1494 * *$ & $0.1605^{* * *}$ & $0.1706^{* *}$ & $0.4768^{* * *}$ & $0.1682^{* * *}$ & $0.1819^{* * *}$ & 0.1996 ** & $0.1217 *$ \\
\hline Germany & $0.1742^{* * *}$ & $0.1802^{* * *}$ & 0.0926 & $0.7429 * * *$ & 0.2174 & $0.1916 * *$ & $0.3629^{*}$ & $0.6604 * *$ \\
\hline Ireland & $0.1437^{*}$ & $0.1293^{*}$ & $0.5652^{* *}$ & $0.7138 * *$ & $0.1373^{*}$ & $0.4067^{*}$ & 0.1679 & $0.1260^{*}$ \\
\hline Italy & 0.0638 & $0.2092^{\text {** }}$ & $0.1543^{* * *}$ & $0.2008^{* * *}$ & $0.1563^{* * *}$ & $0.1355^{*}$ & $0.1841^{* *}$ & $0.1541^{\text {** }}$ \\
\hline Japan & 0.1935 & $0.7158^{* * *}$ & $0.3685^{*}$ & $0.1655^{* * *}$ & 0.1937 & $0.1324 *$ & $0.7493^{*}$ & $0.7405^{* * * *}$ \\
\hline Netherlands & $0.1463^{* *}$ & $0.1491 * *$ & $0.1944 * *$ & $0.1360^{*}$ & 0.1689 & $0.1895 * *$ & $0.1828^{* *}$ & $0.1770^{* *}$ \\
\hline New Zealand & $0.1761 * *$ & $0.1579 * *$ & $0.1209^{*}$ & $0.1191^{*}$ & $0.1845^{* * *}$ & $0.1636^{* * *}$ & $0.1961 * *$ & $0.1504^{* * *}$ \\
\hline Norway & $0.1670 * *$ & $0.1482 * *$ & $0.3640^{*}$ & $0.6568^{* *}$ & $0.2047 * *$ & $0.5087^{* *}$ & $0.1786^{* *}$ & $0.1922^{* *}$ \\
\hline Spain & 0.0828 & 0.1166 & $0.1323^{*}$ & $0.1755^{* * *}$ & 0.1873 & $0.1339^{*}$ & $0.1706^{* *}$ & $0.1212^{*}$ \\
\hline Sweden & $0.1720^{* * *}$ & $0.8011^{* * * *}$ & $0.6802 * *$ & $0.6055^{* * *}$ & $0.1578^{* * *}$ & $0.6193 * *$ & $0.6526^{* * *}$ & $0.1220^{*}$ \\
\hline Switzerland & 0.1250 & $0.7695^{* * * *}$ & $0.7614^{* * * *}$ & $0.1728^{* * *}$ & $0.1486^{* * *}$ & 0.0822 & $0.6134 * *$ & $0.1669^{* *}$ \\
\hline UK & 0.1089 & 0.1002 & 0.1091 & $0.7483^{* * *}$ & 0.1659 ** & $0.5837 * *$ & $0.1687 * *$ & $0.2071 * *$ \\
\hline US & 0.0828 & 0.0579 & $0.6648^{* * *}$ & $0.1650^{*}$ & 0.1836 & 0.6421 ** & 0.1128 & $0.8108^{* * * *}$ \\
\hline
\end{tabular}

Note: *,** and *** indicate statistical significance and rejection of the null at the $10 \%, 5 \%$ and $1 \%$ significance levels, respectively.

Table 8. DF GLS Unit Root Tests.

\begin{tabular}{|c|c|c|c|c|c|c|c|c|}
\hline & $\mathrm{L}_{-} \mathrm{P}_{\mathrm{H}}$ & $\mathrm{L}_{-} \mathrm{Y}_{\mathrm{D}}$ & $\mathrm{L}_{\mathrm{I}} \mathrm{I}_{\mathrm{R}}$ & $\mathrm{L}_{-} \mathrm{C}_{\mathrm{B}}$ & $R_{M}$ & L_T & $\mathrm{L}_{-} \mathrm{D}_{\mathrm{UN}}$ & $\mathrm{L}_{-} \mathrm{D}_{\mathrm{PO}}$ \\
\hline Australia & $-3.3434 * *(2)$ & $1.1423(2)$ & $-3.6010^{* *}(0)$ & $-1.6032(0)$ & $-1.9360(0)$ & $-1.8083(0)$ & $-1.4236(0)$ & -2.4147 (1) \\
\hline Belgium & $-2.0048(1)$ & $-2.1111(1)$ & $-2.6687(1)$ & $-1.9716(0)$ & $-2.0735(0)$ & $-2.7368(0)$ & $-1.3443(2)$ & $0.7741(1)$ \\
\hline Canada & $-2.1178(1)$ & $-2.4168(1)$ & $-2.0962(0)$ & $-2.5001(0)$ & $-2.2776(0)$ & $-2.6380(1)$ & $-2.2917(1)$ & $-0.2323(1)$ \\
\hline Denmark & $-2.2287(1)$ & $-3.5565(1)$ & $-2.2909(1)$ & $-1.3344(0)$ & $-1.2409(1)$ & $-3.4572^{* *}(1)$ & $-1.7794(0)$ & -2.6407 (3) \\
\hline Finland & $-0.8754(2)$ & $-0.1569(1)$ & $-0.2047(2)$ & $-1.0337(1)$ & $-2.4291(0)$ & $-1.6634(0)$ & $-1.9408(2)$ & $0.7674(3)$ \\
\hline France & $-2.2348(1)$ & $-1.7994(1)$ & $-2.3828(1)$ & $-2.1686(9)$ & $-3.5029 * *(5)$ & $-2.1383(1)$ & $-1.0903(1)$ & $-2.1144(3)$ \\
\hline Germany & $-2.2903(1)$ & $-1.8512(1)$ & $-2.7920(1)$ & $-2.2148(3)$ & $-3.0444 *(0)$ & $-2.6613(1)$ & $-0.6728(2)$ & $-2.7134(5)$ \\
\hline Ireland & $-1.1051(2)$ & $-2.3189(1)$ & $-2.0048(1)$ & $1.4717(0)$ & $-2.6496(1)$ & $-2.0251(1)$ & $-2.2024(1)$ & $-2.0772(2)$ \\
\hline Italy & $-3.7382 * *(2)$ & $-0.4867(1)$ & $-2.4839(1)$ & $-1.0405(1)$ & $-1.9224(0)$ & $0.7314(2)$ & $-1.7716(1)$ & $-1.9400(6)$ \\
\hline Japan & $-1.4141(1)$ & $-0.4805(1)$ & $-1.2742(1)$ & $-0.8347(1)$ & $2.2093 * *(0)$ & $-2.2777(4)$ & $-2.4307(1)$ & -0.0403 (3) \\
\hline
\end{tabular}




\begin{tabular}{lcccccccc} 
Netherlands & $-2.8477(1)$ & $-2.2512(1)$ & $-2.4307(1)$ & $-1.5596(0)$ & $-1.8574(0)$ & $-1.3214(1)$ & $-1.9553(1)$ & $-0.2803(3)$ \\
New Zealand & $-2.4246(1)$ & $-1.8206(0)$ & $-1.5781(0)$ & $-1.7367(0)$ & $-1.5606(1)$ & $-2.2838(1)$ & $-1.6523(3)$ & $-2.2003(1)$ \\
Norway & $-2.0006(1)$ & $1.4193(0)$ & $-2.6210(1)$ & $-2.7619(1)$ & $-1.6099(2)$ & $-2.3884(5)$ & $-1.4106(2)$ & $-1.9465(9)$ \\
Spain & $-0.9843(1)$ & $-3.2967^{* *}(1)$ & $-2.7727(1)$ & $-1.9023(1)$ & $-2.0731(0)$ & $-2.4631(1)$ & $-1.6671(1)$ & $-0.5844(2)$ \\
Sweden & $-2.0048(1)$ & $-2.1111(1)$ & $-2.6687(1)$ & $-2.7371(1)$ & $-2.0735(0)$ & $-1.5157(1)$ & $-0.8992(2)$ & $0.8594(4)$ \\
Switzerland & $-3.3277^{* *}(1)$ & $-3.6350^{* *}(1)$ & $0.6439(2)$ & $-1.0659(0)$ & $-3.0205^{*}(0)$ & $-1.3375(0)$ & $-0.9702(1)$ & $-1.0799(5)$ \\
UK & $-3.3294^{* *}(1)$ & $-2.1384(1)$ & $-3.0074^{*}(1)$ & $-1.5648(0)$ & $-3.3030^{* *}(5)$ & $-1.3238(2)$ & $-1.8282(1)$ & $-2.1073(1)$ \\
US & $-4.0891^{* * *}(4)$ & $-3.9661^{* * *}(1)$ & $-3.1131^{*}(1)$ & $-1.8145(0)$ & $-1.5798(2)$ & $-1.0921(1)$ & $-2.1861(2)$ & $-0.7498(2)$ \\
\hline
\end{tabular}

Note: *,** and *** indicate statistical significance and rejection of the null at the $10 \%, 5 \%$ and $1 \%$ significance levels, respectively. Numbers in parentheses show the $\log (\mathrm{s})$.

Table 9. Lag selection.

\begin{tabular}{lcccc}
\hline Selection-order criteria & & & & \\
\hline & lag & AIC & HQIC & SBIC \\
\hline Australia & 2 & -12.7037 & -12.1517 & -11.1523 \\
Belgium & 4 & -15.0459 & -14.0022 & -12.0860 \\
Canada & 2 & -19.0799 & -18.5273 & -17.5125 \\
Denmark & 2 & -3.4588 & -3.1365 & -2.5445 \\
Finland & 4 & -8.7783 & -8.2509 & -6.8768 \\
France & 2 & -14.3994 & -14.0774 & -13.4944 \\
Germany & 3 & -17.8332 & -17.0351 & -15.5693 \\
Ireland & 2 & -9.3157 & -8.9543 & -8.4199 \\
Italy & 4 & -14.3582 & -13.3144 & -11.3976 \\
Japan & 4 & -16.4367 & -15.3930 & -13.4761 \\
Netherlands & 2 & -10.0907 & -9.5380 & -8.5071 \\
New Zealand & 4 & -15.7876 & -14.7466 & -12.7349 \\
Norway & 4 & -17.7750 & -16.1634 & -13.2035 \\
Spain & 4 & -11.7462 & -10.5183 & -8.2631 \\
Sweden & 2 & -14.0897 & -13.3233 & -11.4284 \\
Switzerland & -18.2001 & -17.1564 & -15.2395 \\
UK & 4 & -20.8103 & -19.9661 & -18.4157 \\
US & -18.2444 & -17.2006 & -15.2838 \\
\hline & & & &
\end{tabular}

